\title{
The impact of human behaviour and restoration on the economic lifespan of the proposed Ntabelanga and Laleni dams, South Africa: a system dynamics approach
}

Bester, R. ${ }^{1,}{ }^{*}$, Blignaut, J.N. ${ }^{2,3}$ \& Crookes, D. ${ }^{4}$

${ }^{1}$ Department of Economics, University of Pretoria, Pretoria, South Africa

2School of Public Leadership, Stellenbosch University, Stellenbosch, South Africa

${ }^{3}$ South African Environmental Observation Network, Pretoria, South Africa

${ }^{4}$ ASSET Research, Pretoria, South Africa

* Corresponding author: bester.roz@gmail.com / [P.O. Box 66612, Highveld, Gauteng, 0169]

\section{ABSTRACT}

The South African government intends to develop the Mzimvubu Water Project (MWP) which includes the construction of two dams (the Ntabelanga and Laleni dams) in the Tsitsa River, Eastern Cape province, South Africa. This investment is believed to be important to unlock the economic potential of this rural, poor and underdeveloped area. We consider a range of variables to ascertain what the realistic economic lifespan of each of the dams are, subject to uncertainty and complexity, as the benefits from the development of the dams are closely linked to such lifespans. The selected sites are prone to soil erosion thereby potentially jeopardising the derived benefits from the investment. We therefore develop a catchment-wide system dynamics model, incorporating both technical and behavioural dimensions, in an effort to determine which factors influence the economic lifespan of the dams and to what extent. The results suggest that, without taking any restorative or behavioural effects into consideration, the lifespan of the Ntabelanga and Laleni dams are 55-68 years and 26-33 years, respectively. Introducing business-as-usual type behavioural patterns could reduce the dams' lifespans by between $35 \%$ and $44 \%$ due to the increased erosion. The increased soil erosion and resulting sedimentation is the direct result of increased human and animal movements due to the economic investment and associated land use change. Restorative and desirable behavioural action that will mitigate these impacts have the potential to reduce this loss to only $4 \%-9 \%$. This would imply investing heavily both in restoration and in capacity-building and community development programmes to facilitate desirable behavioural change. In sum, this suggests that investment in social and natural capital has to coincide with the investment of financial capital in manufactured capital to make economic development last. Investment in social and natural capital could therefore be viewed as a type of insurance policy, and thus an insurance investment, against the risk of very plausible losses 
of the benefits derived from the manufactured capital (the dams). Alternatively, the opportunity cost of not investing in social and natural capital, is the much reduced lifespans of the dams and all associated economic benefits.

\section{Highlights:}

- Variability in soil erosion in a catchment cause a dam's actual and predicted economic lifespan to differ significantly.

- When no mitigation is assumed the modelled Ntabelanga dam's lifespan declines from 55-68 years to $31-44$ years. With mitigation, the anticipated lifespan is $50-65$ years.

- When no mitigation is assumed the modelled Laleni dam's lifespan declines from 26-33 years to $16-21$ years. With mitigation, the anticipated lifespan is $24-30$ years.

- The state of the catchment has to be improved and maintained through restorative actions together with societal endorsement and behavioural change. Such behavioural change is to be informed by a catchment management plan and the proactive and careful implementation thereof.

- The investment in social and natural capital to safeguard the lifespan of the manufactured capital (the dams) and thus the financial capital invested, is of high importance.

Keywords: system thinking, dams, economic lifetime, soil erosion, human behaviour, restoration

\section{$1 \quad$ INTRODUCTION}

It is the government of South Africa's intent to develop the proposed Mzimvubu Water Project (MWP). This project comprises the construction of two dams (the Ntabelanga and Laleni dams) in the Tsitsa River, in the Eastern Cape Province. This development is to be augmented with investments in an irrigation scheme to further agricultural activity and kick-start subsequent economic development in the coming decades. This proposed development is of high strategic importance as the uMzimvubu river catchment is characterised by high levels of poverty, with low levels of employment, little economic activity and an increasing reliance of households on social assistance [1*].

While such an initiative is praiseworthy, the question is, what are the drivers to success of such an initiative? One of the key, yet often overlooked or neglected, drivers is the realistic economic lifespan of the dams. The expected economic lifespan of a dam is the period before a dam is silted up and during which it is likely to deliver economic benefits. This lifespan is calculated as [2*]: 


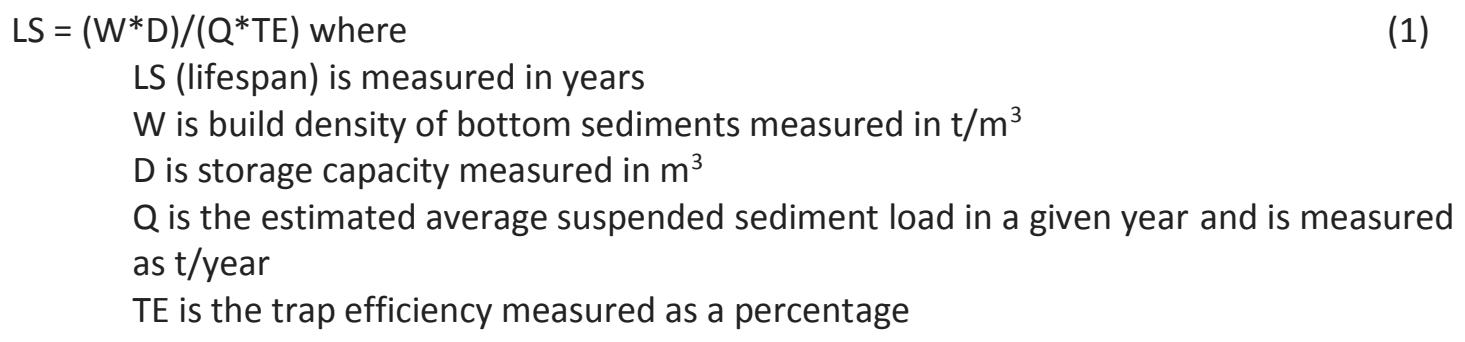

From equation 1 it is clear that several factors influence the anticipated economic lifespan of a dam. Of particular importance here is the fact that generally as $Q$, the suspended sediment, increases, the economic lifespan of the dam decreases, and the converse is true as well. Careful attention should therefore be given to this as an increase in suspended sediment load accelerates dam sedimentation and is a negative externality. This is since it leads to losses in the assurance of water supply [3*], water yield, changes in estuarine activity and fish production [4*], and losses in hydropower capabilities [5*, 6*]. Therefore, estimates of dam lifespans that include time trends of suspended sediment loads are of great value. We acknowledge, however, that even though the techniques/skills/data required to produce sediment adjusting estimates go beyond those used in traditional economic analysis, we also argue that the consequences of ignoring it is very grave and therefore it is important to include it in economic analysis.

We use the planned Mzimvubu Water Project (MWP) that comprises the construction of two dams (the Ntabelanga and Laleni dams) in the Tsitsa River, Eastern Cape province, South Africa, as a case study and we propose a method based on modelling the anticipated impacts of anthropogenic behavioural changes on soil movements to estimate changes in dam lifespans. Before providing the details of this case study, we examine plausible reasons why the modelling and estimations of expected dam lifespans have failed to develop some sophistication in the past. This is done particularly with respect to human-induced trends in erosion processes.

\section{MODELLING THE ECONOMIC LIFESPAN OF A DAM: BACKGROUND}

Systems thinking is defined by Arnold and Wade [7:675] as "a set of synergistic analytic skills used to improve the capability of identifying and understanding systems, predicting their behaviors, and devising modifications to them in order to produce desired effects". It is a paradigm and a learning method that enables one to think more productively about a world that is increasingly marked by awareness of interconnectedness and complex behaviours. System dynamics and system dynamics modelling on the other hand are, respectively, an approach and a tool with which to comprehend a system's structure and run simulations around that comprehension both of which require a specific 
skill sets and accompanying competencies [8]. Ironically such prerequisites have encouraged the emergence of steep barriers to entry reinforcing the reductionist fragmentation of human knowledge generating capacity and effectively limiting the extent to which systems can be understood and sensible modification to them proposed.

Viewing the matter of dam lifespan estimates through the lens of systems thinking, it is learned that, for the most part, civil engineers contracted to build dams are under no obligation to collect or verify sedimentation data before or during a project [9]. Therefore they cannot guarantee that the dam will survive the impacts of sedimentation long enough to provide economic benefits over some average expected period of time. There are also no penalties incurred if the dam's lifespan is less than predicted or assumed. The burden of monitoring and evaluating the dam's capacity falls upon government departments who are also not held accountable for dam lifespan as much as for ensuring that the necessary water yield exists to meet demand. The latter is easily accomplished by contracting engineers to raise dam walls, build transfer schemes, erect desalination plants or increase the number of impoundments on a river [10]. There are of course a range of possible reasons for the existence of such an oversight, such as :

1. Both government and engineering firms stand to benefit financially from this arrangement.

2. There are many dams that tend to silt up slowly and have long expected lifespans $[11,12]$ spanning centuries, and if the anticipated lifespan of the dam is very short, then it is likely to raise serious ideological and practical concerns as to the need for the dam [13].

3. By and large people do not have planning horizons rivalling the length of the construction project they are engaged in - for example, politicians often are unconcerned with what occurs after their term in office [14].

Furthermore, one is often discouraged from pursuing this type of analysis when considering the magnitude thereof. Not only are the estimates of suspended sediment subject to change over time but also, long after the completion of a particular study or research, are sediment yield estimates or data on remaining usable storage capacity of a dam scarce and expensive to produce $\left[4^{*}, 15\right]$. Additionally, modelling future sediment yields is subject to much change since the average suspended sediment load will vary according to :

1. seasons $\left[6^{*}, 16,17,18,19\right]$

2. response to climate change $[3 *, 20,21]$

3. changes in upstream impoundments $[4 *, 22,23]$

4. long run upstream land use changes $[24,25,26]$ 
5. changes in dam operating strategies $[27,28,29]$

The degree of soil movement is further affected by the scale of economic activity, human population densities, and different forms of manufactured capital that are introduced into the system [30]. As a consequence, a variety of models and modelling techniques have been developed by subject experts to estimate the level and rate of sedimentation for differing levels of data availability [31, 32, 33, 34]. These complicated models are inaccessible to most decision-makers and economic analysts, thus requiring the coordinated efforts of a heterogeneous group of experts covering various disciplines such as restoration ecologists, hydrologists, geologists, economists and, in some instances, animal scientists, sociologists, and policy makers. The costs of hiring the services of such a group of experts and facilitating their interactions is likely to be very high.

Fortunately, the changes in soil movements following various forms of human intervention are, by and large, measurable and these can and are being modelled to some extent [35]. For example, reduction in soil losses have been measured i) when an area is reforested [36], ii) where more effective soil conservation technologies are implemented [19], and iii) where gullies are restored [22]. Some estimates including the impact of land use changes, if these can be forecasted or planned, are therefore achievable. However, instead of speculating what sort of land use changes will occur in a region, we propose that an efficient model of expected lifespan can be built around the plausible changes in human behaviour focussing on the impacts on sediment yields of changes in the stock of social capital over time. We develop a system dynamics model to illustrate this theory at the hand of a case study. The development of a simulation model is intended as nothing more than a boundary object in service of the suggested research agenda and assisting diverse stakeholders to integrate their perspectives and legitimise a sense of ownership over the problem [37]. To this end we endeavour to convey the interconnectedness of the system by extending the models boundary to cover the entire river system inclusive of the interest's natural scientists while also focussing on human behaviour as the driver representing the interest of all social scientists.

\section{MATERIALS AND METHOD}

The system dynamics model developed in this study estimates the lifespans of the Ntabalenga and Laleni dams in the Tsista River, Eastern Cape province, South Africa by considering the plausible impacts of future anthropogenic developments and their mutual dependence on each other. We start 
by describing the study area, followed by a literature review of site specific characteristics. Thereafter, we discuss the model, and then present the results of the Monte Carlo simulation analysis.

\subsection{Description of the study area}

The Ntabelanga dam catchment (approximately $1967 \mathrm{~km}^{2}$ ) and the Laleni dam catchment (approximately $1882 \mathrm{~km}^{2}$ ) are part of the larger uMzimvubu river catchment (approximately $20000 \mathrm{~km}^{2}$ ) situated between the south-eastern border of Lesotho and the Indian Ocean (see Figure 1). This larger catchment produces the fourth highest mean runoff (approximately $2.8 \mathrm{x}$ $10^{9} \mathrm{~m}^{3} /$ annum) in South Africa [38]. The uMzimvubu river is therefore a natural choice for impoundments due to its size, location and largely still "untapped" status within an area of economically impoverished population. In 2011, the average monthly household income in the uMzimvubu river catchment was R3 183.33 [39] ( US\$250/month) which is half of the average monthly household income for the entire Eastern Cape province [40]. In addition, the South African national electricity generation utility, ESKOM, has been investigating the suitability of the Tsitsa falls as a suitable location for hydropower generation since 2001 [41].

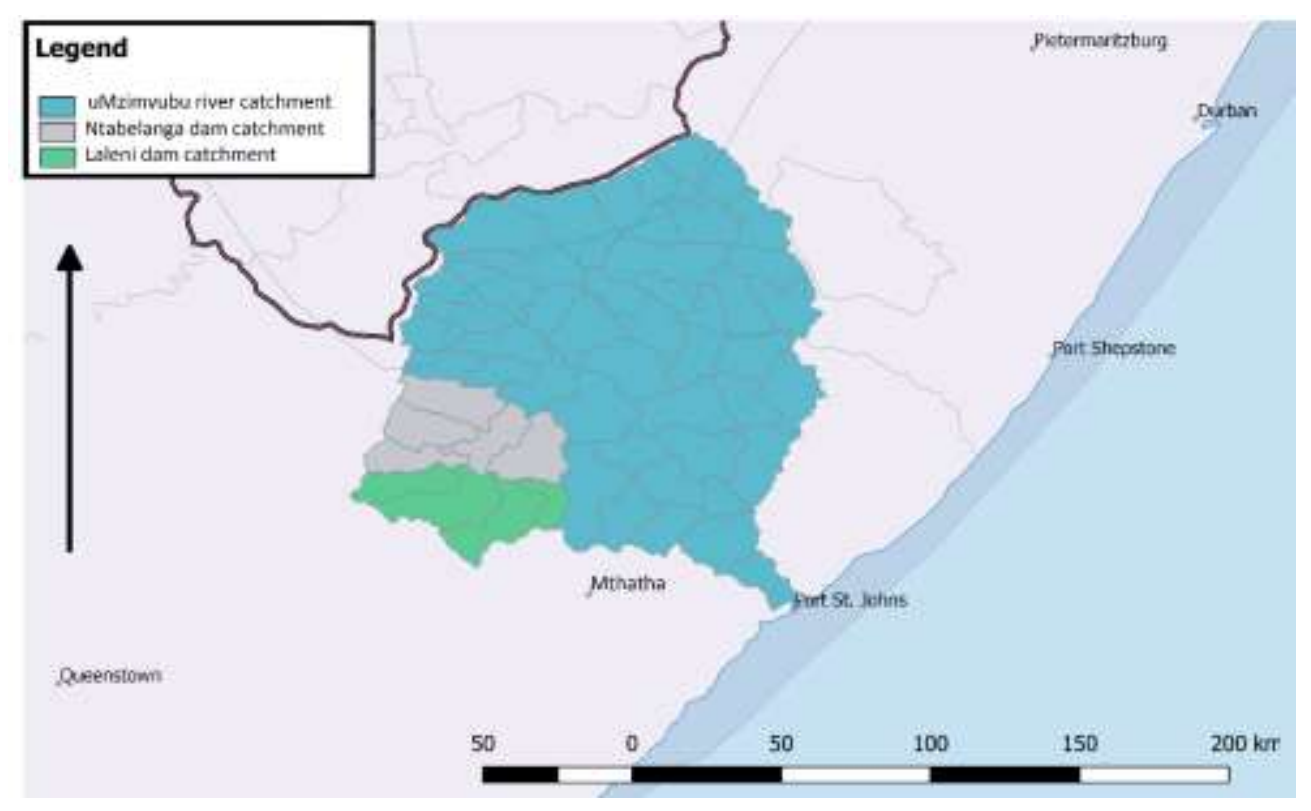

Figure 1 Study Area: Mzimvubu river catchment

Source: Own construction using river and drainage region data from the Department of Water Affairs as well as natural earth data

In terms of conservation importance relating to biodiversity, the estuary at the uMzimvubu river mouth at Port St. Johns (approximately $240 \mathrm{~km}$ south-west of Durban and $70 \mathrm{~km}$ east of Mthatha), is ranked 35th out of South Africa's 265 estuaries [42]. It has a total surface area of approximately 150ha 
[43] and contributes roughly R6 783215 ( US\$522 000) per annum to marine fisheries [44]. This return is under threat since the catchment produces high sediment yield rates, is considered to be in a poor condition and is subject to probable future deterioration $[45,46]$.

\subsection{Economic development prospects}

The uMzimvubu Water Project (MWP), is expected to catalyse growth in economic activity across the Eastern Cape which implies the development of the catchment. Thus a substantial increase in household income is expected within the study area during their operational years [47]. The local inhabitants who are aware of the planned development have high expectations that the construction of the larger Ntabelanga irrigation dam will allow for the expansion of irrigation agriculture while reducing the high rates of soil erosion that currently destroy their homes and disrupt graves. Such expectations are disconcerting as most of the gully erosion currently occur in areas previously used for crop cultivation [48]. Yet, it is the expectations of the local inhabitants that will determine their future behaviour. As the saying goes, the best gauge for future behaviour is past behaviour. Therefore, these concerns remain, even if the proposed restoration programme implemented in the Ntabelanga and Laleni dam catchments is highly successful [49].

We therefore seek to internalise a range of plausible societal behavioural patterns and the need for improving the economic development prospects and the impacts that might have on the expected life expectancies of the dam. We turn to the model design now.

\subsection{Model conceptualisation}

None of the official documents related to the MWP report on the projected lifespans of the dams [39, $1,47,49,43]$. An external study focussing only on possible soil movements, however, suggests that the lifespan of the Ntabelanga dam is 55 years while the Laleni dam is 43 years [45]. Land use data is mentioned as an important factor in most of these studies and is used in the calculation of dam lifespan and sedimentation. The modelling thereof over time, however, is not taken into consideration. This is a major shortcoming and one that we wish to address. One major constraint is that there exists no long-term data since the MWP is only a proposed scheme, and the variables impacting the dams' economic lifetime listed in Annex 1 are not adequately captured in a systematic manner. Available data include single entry point observations/estimates related to soil movement, the proximity of erosion gullies, and mean annual runoff, as well as the physical properties of the dams 
$[50,51]$. Within a separate dataset, socio-economic time series data, including household income and demographic data is recorded at municipal level $[40,52,53]$. Of great interest are projected income growths for the Mzimvubu catchment [47]. This enables a mapping of all the required data for the modelling process.

We choose to augment the current dam lifespan estimates by including the impact on long run sediment yield trends caused by behavioural adaptation of communities. To do so we model the underlying processes that govern land use change and agricultural behaviour over time. By behavioural adaptation we mean the "process by which individuals learn, negotiate, enact and maintain the behaviours appropriate to a given environment..." [54]. In this particular case study, we refer to households in the Mzimvubu catchment adopting behavioural patterns to minimise soil loss. Bruque [55] provides empirical evidence to suppose that the size and strength of supportive and informative networks are good predictors of adaptation. This provides us with a way to understand what one of the impacts will be on social capital stocks change in the catchment over time.

We model two potential vectors of adaptation. The direction of these vectors can be understood as (1) adaptation over time for growing population and affluence in the catchment due to a strengthening of networks, and (2) a deterioration of networks in the presence of growing populations and increasing incomes over time. The magnitude of the behavioural change we model as a function of household income. We define three elasticities to model the consequences of growing populations and incomes over the long-term average sediment yield rate. These elasticities decrease over time when modelling the desirable behavioural adaptation in the presence of increasing social capital in the study area; and these elasticities increase over time when modelling undesirable behavioural adaptation in the presence of diminishing social capital.

The model consists of 81 equations, 12 of which are differential equations describing the rates of change of sediment yields, usable dam storage capacities, impacts on the estuary downstream, changes to population densities, household income and the impacts of some restoration efforts over time and relative to one another (refer to Annex 1 for parameter values used to calibrate these equations). We do not model income, but rather anticipated changes to the projected income growth [47] due to soil loss affecting agriculture and estuary health.

Given the limited data, we seek to vary key parameters within reasonable ranges and default to sensitivity analysis in such a way that the estimates of the dams' lifespans are produced in terms of 
confidence intervals. The reduction of the complexity of such a system is accomplished through a system dynamics approach to modelling, which also enables us to examine in some detail the longterm implications of feedbacks and delays which are so prevalent in understanding sediment movement over time. The model of the Mzimvubu catchment system is summarised and briefly explained in the causal loop diagram in Figure 2. A detailed explanation of all the numbered links are provided in Annex 2, with a validation suitable to the type of modelling approach provided in Annex 3.

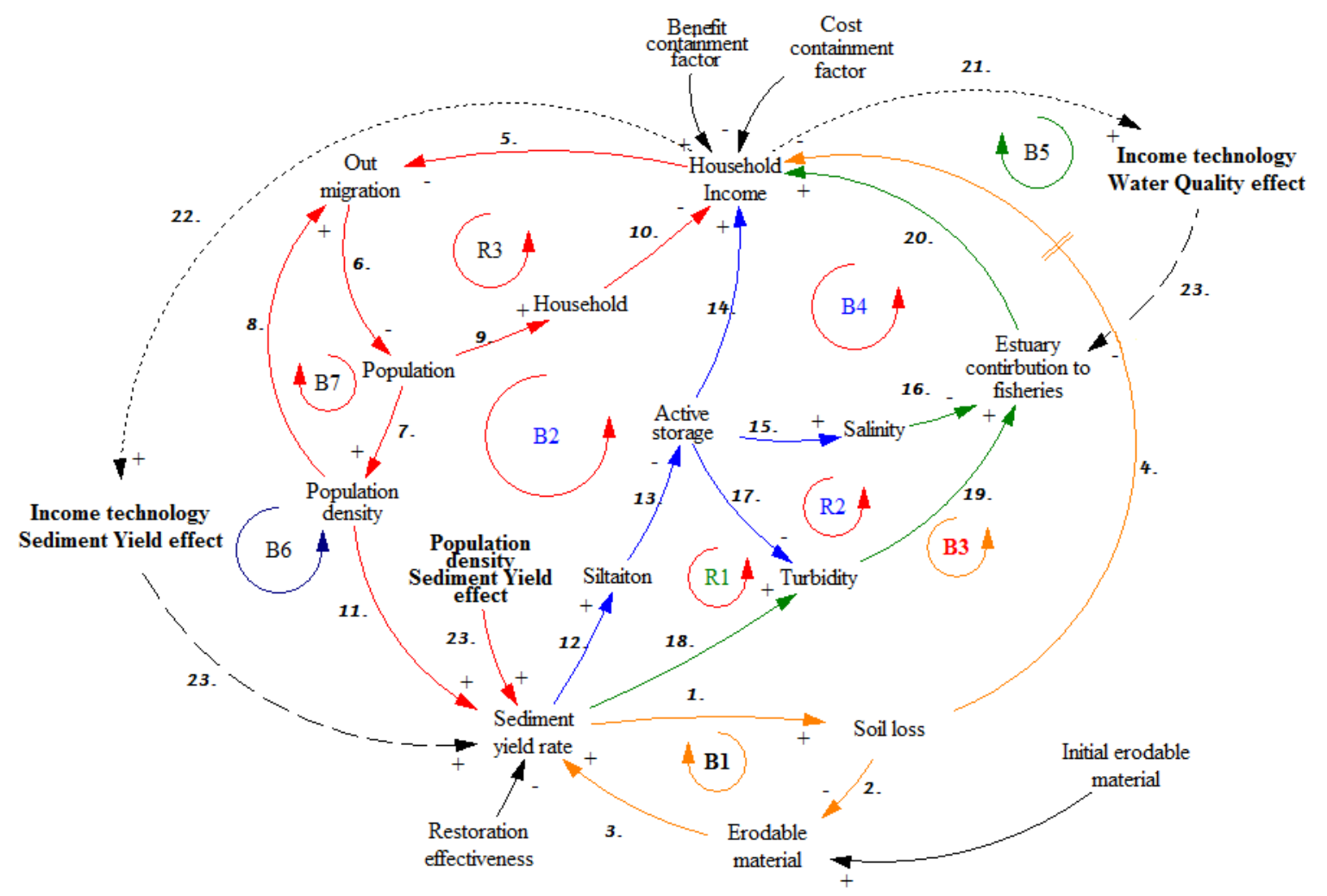

Figure 2 CLD describing the Mzimvubu river catchment system; relationships labelled 1-26 are explained in further detail in Annex 2

Source: Own construction

The model's dynamics are provided by the following important causal loops (Figure 2):

1. A mechanism (loop B1) that limits the rate of soil loss from the catchment.

2. A direct positive relationship (population density income elasticity) which is defined to exist between population density and soil erosion processes, which models two aspects of population dynamics:

a. higher local income eroding incentive to migrate (loop R3); and

b. higher population density encouraging migration (loop B5).

3. Three environmental checks and balances are given on income growth: 
a. the impact of soil loss, through loss of soil fertility on future agricultural production (loop B3);

b. the reduction of dam storage and thus economic benefits provided by water project as a result of siltation (loop B2); and

c. the impact of water salinity and turbidity on estuarine production (loops R1, R2 and B4).

4. Two additional regulating feedback mechanisms (dotted black arrows):

a. a direct delayed positive relationship (Income Sediment yield elasticity) which exists between income and sediment yield rates (loop B6); and

b. a direct positive relationship (Income Water quality elasticity) which exists between income and water quality that will impact the estuary function (loop B5).

This allows us to estimate the impact of various technical and behavioural interventions on the dams' lifespans. A main feature of this model (elaborated in Annex 2) is the assumed nature of the relationships between household income, human behaviour and the sediment yield rate over time. As stated above, through a system thinking lens, the simulation model and associated CLD is intended only as a boundary spanning object. Livelihoods are intertwined with water quality and the functionality of the river system. The estuary is selected to represent this concept of interrelatedness even though the analysis of this relationship is not thoroughly defined or explored. This model is a prototype which is purposed to engender greater collaborative interests and efforts around economic lifespan as a focal point or indicator to support integrated water resource management efforts.

\subsection{Monte Carlo parameter scenarios}

The model described in Section 3.3 is used to conduct a sensitivity analysis based on Monte Carlo simulation (see Table 1). We commence with variations for the basic (also called the naïve) mix of parameters that are listed within the literature and for which the literature provides various values. It should be noted that for this model we assume that changes in income do not have an effect on behavioural change. 
Table 1 Parameter variation mixes used in sensitivity analysis

\begin{tabular}{|c|c|c|c|}
\hline Mix name & Parameters & $\begin{array}{l}\text { Measuring } \\
\text { Unit }\end{array}$ & $\begin{array}{l}\text { Range of values } \\
\text { used within } \\
\text { Monte Carlo } \\
\text { analysis }\end{array}$ \\
\hline Naïve model ${ }^{1}$ & $\begin{array}{l}\text { Bulk density } \\
\text { Initial average sediment yield rate } \\
\text { Trapping efficiency Laleni } \\
\text { Trapping efficiency Ntabelanga } \\
\text { Subst. switch = } 0 \text { (linear relationship - see } \\
\text { Annex 2, Figure 3) }\end{array}$ & $\begin{array}{c}\mathrm{t} / \mathrm{m}^{3} \\
\mathrm{t} / \mathrm{ha} / \mathrm{annum} \\
\% \\
\%\end{array}$ & $\begin{array}{c}(1.5,1.7) \\
(62,82) \\
(95,100) \\
(95,100)\end{array}$ \\
\hline Anthropogenic effects & $\begin{array}{l}\text { Naïve model } \\
\text { + Population density sediment yield elasticity } \\
\text { + Income sediment yield elasticity } \\
\text { + Sediment yield effect delay } \\
\text { + Response time }\end{array}$ & $\begin{array}{l}\text { Dmnl }^{2} \\
\text { Dmnl } \\
\text { Months } \\
\text { Dmnl/year }\end{array}$ & $\begin{array}{c}(3,7) \\
(3,7) \\
(12,60) \\
(0.5,1.5)\end{array}$ \\
\hline Restoration effects & $\begin{array}{l}\text { Anthropogenic effects } \\
\text { + Restoration duration } \\
\text { + Restoration budget } \\
\text { + Probability of structure failure } \\
\text { + Sediment yield restoration effect } \\
\text { + Restoration duration }\end{array}$ & $\begin{array}{l}\text { Months } \\
\mathrm{R}^{3} \\
\text { Dmnl } \\
\text { \%/ha/Months }\end{array}$ & $\begin{array}{c}(100,140) \\
(4 \mathrm{~m}, 5 \mathrm{~m}) \\
(0,0.06) \\
(0.4,0.6)\end{array}$ \\
\hline Environmental effects & $\begin{array}{l}\text { Restoration effects } \\
\text { + Water quality elasticity } \\
\text { + Cost containment } \\
\text { + Water quality effect delay } \\
\text { + Soil loss impact } \\
\text { + Estuary impact } \\
\text { + Benefit containment effect }\end{array}$ & $\begin{array}{c}\mathrm{Dmnl}^{2} \\
\% \\
\text { Months } \\
\% \\
\% \\
\% \\
\end{array}$ & $\begin{array}{c}(3,7) \\
(0.01,0.15) \\
(12,60) \\
(0,1 \mathrm{e}-11) \\
(0.0001,0.001) \\
(0.5,0.8) \\
\end{array}$ \\
\hline $\begin{array}{l}\text { Desirable income } \\
\text { substitution }\end{array}$ & $\begin{array}{l}\text { Environmental effects } \\
+ \text { Subst. switch = } 2 \text { (logarithmic relationship - } \\
\text { see Annex 2, Figure A2-3) }\end{array}$ & & \\
\hline $\begin{array}{l}\text { Undesirable income } \\
\text { substitution }\end{array}$ & $\begin{array}{l}\text { Environmental effects } \\
+ \text { Subst. switch = } 1 \text { (exponential relationship - } \\
\text { see Annex 2, Figure A2-3) }\end{array}$ & & \\
\hline
\end{tabular}

Notes:

1. For the naïve model: Bulk density estimated as $1.6 \mathrm{t} / \mathrm{m}^{3}$ sediment yield rate is based on $72 \mathrm{t} / \mathrm{ha}$ /annum [50]; trapping efficiency for Ntabelanga is calculated as 0.978 and trapping efficiency for Laleni is based on figures for dam capacity and mean annual runoff found in Annex 1.

2. Dmnl is the abbreviation for dimensionless common to system dynamics modelling.

3. $\mathrm{R}$ is the abbreviation for the South African Rand.

4

RESULTS

The construction of the MWP was due to commence in 2014, but it has been delayed several times. We therefore present the results in terms of operational months starting at an unknown future date, with month 1 being the start of the construction of the Ntabelanga dam. It is anticipated that this dam 
will be completed at month 72 and the Laleni dam 96 months into the simulation period. The model runs for a total number of 906 months or 75 years.

A baseline reading from the model, that is the reading without allowing for the Monte Carlo analysis, indicates a lifespan of 57 years when no attempt is made to correct for the impact of increasing populations and incomes on sediment yields over time. The outcome differs slightly from the 55 year calculation mentioned earlier [45]. This difference can be explained as the trapping efficiencies used were not assumed to be $100 \%$ throughout for both dams with monthly variation in trap efficiency values randomly sampled from a uniform distribution for some range of trap efficiency values. The estimates of dam lifespan for the Laleni dam differ considerably from the 43 year reported earlier [45]. An explanation for this is that the sediment yield rate used to calibrate the model was derived from observations from the Ntabelanga dam catchment and applied for the entire Mzimvubu river catchment [51]. The earlier study focussed on differences between the Ntabelanga and Laleni dam catchment, the latter of which was found to have a sediment yield much lower than the first [45]. This highlights the dependency of these lifespan estimates on sediment yield figures and the pitfalls of estimating lifespans where data is scarce.

Table 2 (see also Annex 4) summarises the results with respect to the anticipated lifespans of the two dams when considering different scenarios. These lifespans are reported as the intervals (in years) in which $75 \%$ of the simulations for various parameter mixes converge indicating the respective dams being silted up. These results indicate:

1. There is a substantial reduction in the anticipated lifespans when incorporating business-asusual type anthropogenic effects on-top of the naïve model. The anticipated lifespan of the Ntabelanga dam, for example, declines from 55-68 years to 31-44 years and that for the Laleni dam from $26-33$ years to $16-21$ years.

2. When incorporating the restoration and environmental effects, as well as income leakage and desired behavioural changes, the anticipated lifespans increase each time to reach a maximum lifespan of 50-65 years (Ntabelanga dam) and 24-30 years (Laleni dam).

3. In the event of undesirable behavioural action, however, the anticipated lifespan is reduced to $31-45$ years and $15-20$ years. 


\begin{tabular}{|c|c|c|c|c|c|c|c|}
\hline \multirow[t]{2}{*}{ Mix name } & \multirow{2}{*}{ 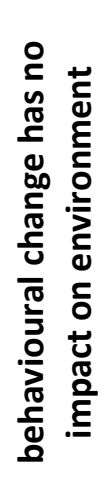 } & \multirow{2}{*}{ 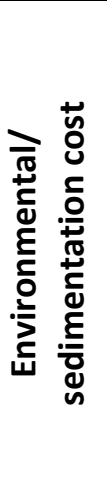 } & \multicolumn{2}{|c|}{$\begin{array}{c}\text { (1) } \\
\text { Ntabelanga } \\
\text { lifespan (years) } \\
75 \% \text { of simulations } \\
\text { fall between }^{1}\end{array}$} & \multicolumn{2}{|c|}{$\begin{array}{c}\text { (2) } \\
\text { Laleni lifespan } \\
\text { (years) } 75 \% \text { of } \\
\text { simulations fall } \\
\text { between }{ }^{1}\end{array}$} & \multirow[t]{2}{*}{$\begin{array}{l}\text { Additive } \\
\text { impact }\end{array}$} \\
\hline & & & Min & Max & Min & Max & \\
\hline Naïve model & $x$ & & 55 & 68 & 26 & 33 & \\
\hline $\begin{array}{l}\text { + Business-as-usual } \\
\text { anthropogenic effects }\end{array}$ & $x$ & & 31 & 44 & 16 & 21 & Reduce \\
\hline + Restoration effect & $x$ & & 33 & 46 & 17 & 23 & Increase \\
\hline $\begin{array}{l}\text { + Desirable behavioural change } \\
\text { and income substitution }\end{array}$ & & $\mathrm{x}$ & 50 & 65 & 24 & 30 & Increase \\
\hline $\begin{array}{l}\text { + Undesirable behavioural } \\
\text { change and income substitution }\end{array}$ & & $\mathrm{x}$ & 31 & 45 & 15 & 20 & Reduce \\
\hline
\end{tabular}

$1 \quad$ Note: Results rounded to the nearest year

\section{CONCLUSION}

In a water resources catchment, the lifespan of a dam is an emergent property embedded in the interrelatedness of many complex and dynamic elements. While the scientific understanding of each individual element can be sophisticated, our capacity to model the interactions among them is limited. Scientific knowledge and subject expertise and local/indigenous knowledge, or wisdom, has to be combined to construct integrative catchment modelling. This is especially true with respect to the modelling of the anticipated lifespans of dams under various scenarios and/or conditions. Using a systems thinking approach it is possible to produce sediment adjusted estimates of dam lifespans in an integrative manner across disciplines. This provides an important bridge between the research and management divides and thus offers an important leverage point towards sustainable management of water resources in future.

In an attempt to simplify the complexity around modelling dam lifespans, we suggest an approach built around the impacts of social capital on soil loss through income related changes to human behaviour. 
Economic development depends, among others, on the injection of financial resources and the development of manufactured capital that could be used as a springboard for further development. As such it is the government's intent to develop the proposed Mzimvubu Water Project (MWP) comprising the construction of two dams (the Ntabelanga and Laleni dams), including an irrigation scheme, in the Tsitsa River. The question though is, what are the realistic economic lifespans of the dams? Here, we develop a catchment-wide system dynamics model incorporating both technical and behavioural dimensions, and an effort to model the influence of social capital on the economic lifespan of the two dams. This is important as the catchments are already degraded and prone to further soil degradation, negatively affecting the anticipated lifespans. The current engineering studies neither take these into account and nor do they consider the impacts of various anthropogenic behavioural changes.

In the absence of appropriate adaptation, the impact of restoration in lengthening the lifespan of both modelled dams is negligible. By making some inclusion for the loss of soil and estuary health on household income, the modelled system adjusts to lengthen the dam lifespans by slowing down the speed at which households increase the scale or type of operation. The results signal the importance of behavioural action.

We show that, considering a capital investment project of this magnitude, without taking into consideration both environmental and anthropogenic feedback effects, this is highly likely to lead to erroneous conclusions. It is equally as important to invest in both environmental and society-wide programmes towards safeguarding the investment programme. The responsibility of the investment planner does not stop at calculating the cost of the capital investment but extends towards making sure that such an investment is durable and to take the necessary steps in this regard. In this case it would imply investing heavily both in restoration and in capacity-building and community programmes to facilitate desirable behavioural change.

Desirable behavioural change in conjunction with restoration and prudent environmental management will buy almost an equal number of years for the project as what would have been lost if it was not the case. Buying back the years that would have been lost due to the initial unmitigated anthropogenic behaviour will extend the dams' lifespans. For the modelled Ntabelanga dam, for example, the unmitigated anthropogenic effects are expected to reduce the dam's lifespan by $35 \%-$ $44 \%$ (44 years compared to 68 years and 31 years compared to 55 years). Introducing restorative 
actions and desirable behavioural action will reduce this loss to only 4\%-9\% (comparing 65 years with 68 years and 50 years with 55 years).

Investing in social and natural capital has to coincide with the investment of financial capital in manufactured capital to make the economic development last. Investment in social and natural capital could therefore be viewed as a type of insurance policy, and thus insurance investment, against the very plausible losses in the benefits derived from the dams. Alternatively, the opportunity cost of not investing in social and natural capital, is the much-reduced lifespans of the dams and all associated economic benefits.

\section{Acknowledgements}

We would like to acknowledge DEA:NRM and the South African Environment Observation Network (SAEON) for their support and Leandri van der Elst for editing the manuscript.

\section{REFERENCES}

[1] Westaway, A. 2012. Rural poverty in the Eastern Cape Province: Legacy of apartheid or consequence of contemporary segregationism? Development Southern Africa, 29:115-125.

[2] Hay, B.J. 1994. Sediment and water discharge rates of Turkish Black Sea rivers before and after hydropower dam construction. Environmental Geology, 23(4):276-283.

[3]Graf, W., Wohl, E., Sinha, T. \& Sabo, J. 2010. Sedimentation and sustainability of western American reservoirs. Water Resources Research, 46. http://dx.doi.org/10.1029/2009wr008836.

[4]Gunatilake, H. \& Gopalakrishnan, C. 1999. The Economics of Reservoir Sedimentation: A Case Study of Mahaweli Reservoirs in Sri Lanka. International Journal of Water Resources Development, 15(4):511-526, http://dx.doi.org/10.1080/07900629948736

[5]Abdelhadi, M. 1994. Relationship between erosion and energy in North Africa. Renewable Energy, 5:1520-1529. http://dx.doi.org/10.1016/0960-1481(94)90201-1.

[6]Hadihardaja, I. 2009. Decision support system for optimal reservoir operation modeling within sediment deposition control. Water Science \& Technology, 59:479. http://dx.doi.org/10.2166/wst.2009.869.

[7]Arnold, R.D. \& Wade, J.P. 2015. A definition of systems thinking: a systems approach. Procedia Computer Science, 44:669-678.

[8]Richmond, B. 1994. Systems thinking/system dynamics: let's just get on with it. System Dynamics Review, 10(2-3):135-157.

[9]McCully, P. 1996. Silenced rivers: The ecology and politics of large dams. Zed Books.

[10]Crookes, D.J. 2018. Does the construction of a desalination plant necessarily imply that water tariffs will increase? A system dynamics analysis. Water Resources and Economics.

[11]Moussa, A.M.A. 2013. Predicting the deposition in the Aswan High Dam Reservoir using a 2-D model. Ain Shams Engineering Journal, 4(2):143-153.

[12]Yang, J. 2016. EMergy accounting for the Three Gorges Dam project: three scenarios for the estimation of non-renewable sediment cost. Journal of Cleaner Production, 112:3000-3006. 
[13]Jebari, S., Berndtsson, R., Bahri, A. \& Boufaroua, M. 2010. Spatial soil loss risk and reservoir siltation in semi-arid Tunisia. Hydrological Sciences Journal-Journal des Sciences Hydrologiques, 55(1):121-137.

[14]Schmitter, P.C. 1994. Dangers and dilemmas of democracy. Journal of Democracy, 5(2):57-74.

[15]Issa, E.I., Al-Ansari, N., Knutsson, S. \& Sherwany, G. 2015. Monitoring and Evaluating the Sedimentation Process in Mosul Dam Reservoir Using Trap Efficiency Approaches. Engineering, 7:190-202. http://dx.doi.org/10.4236/eng.2015.74015.

[16]Hantush, M. \& Kalin, L. 2005. Uncertainty and sensitivity analysis of runoff and sediment yield in a small agricultural watershed with KINEROS2 / Analyse d'incertitude et de sensibilité des siPopulation density SY effectlations d'écoulement et de transport solide de KINEROS2 dans un petit bassin versant agricole. Hydrological Sciences Journal, 50. http://dx.doi.org/10.1623/hysj.2005.50.6.1151.

[17]Lewis, S., Bainbridge, Z., Kuhnert, P., Sherman, B., Henderson, B., Dougall, C., et al. 2013. Calculating sediment trapping efficiencies for reservoirs in tropical settings: A case study from the Burdekin Falls Dam, NE Australia. Water Resources Research, 49:1017-1029. http://dx.doi.org/10.1002/wrcr.20117.

[18]Butt, M., Mahmood, R. \& Waqas, A. 2011. Sediments deposition due to soil erosion in the watershed region of Mangla Dam. Environmental Monitoring and Assessment, 181:419-429. http://dx.doi.org/10.1007/s10661-010-1838-0.

[19]Lee, Y., Yoon, T. \& Shah, F. 2013. Optimal Watershed Management for Reservoir Sustainability: Economic Appraisal. Journal of Water Resource Planning and Management, 139:129-138. http://dx.doi.org/DOI: 10.1061/(ASCE)WR.1943-5452.0000232.

[20] Khan, N. \& Tingsanchali, T. 2009. Optimization and simulation of reservoir operation with sediment evacuation: a case study of the Tarbela Dam, Pakistan. Hydrological Processes, 23:730-747. http://dx.doi.org/10.1002/hyp.7173.

[21]Kumar, S., Raghuwanshi, N. \& Mishra, A. 2015. Identification and management of critical erosion watersheds for improving reservoir life using hydrological modeling. Sustainable Water Resources Management, 1:57-70. http://dx.doi.org/10.1007/s40899-015-0005-8.

[22]Maalim, F., Melesse, A., Belmont, P. \& Gran, K. 2013. Modelling the impact of land use changes on runoff and sediment yield in the Le Sueur watershed, Minnesota using GeoWEPP. CATENA, 107:35-45. http://dx.doi.org/10.1016/j.catena.2013.03.004.

[23]Minear, J. \& Kondolf, G. 2009. Estimating reservoir sedimentation rates at large spatial and temporal scales: A case study of California. Water Resources Research, 45. http://dx.doi.org/10.1029/2007wr006703.

[24]Erskine, W., Mahmoudzadeh, A. \& Myers, C. 2002. Land use effects on sediment yields and soil loss rates in small basins of Triassic sandstone near Sydney, NSW, Australia. CATENA, 49:271-287. http://dx.doi.org/10.1016/s0341-8162(02)00065-6.

[25]Montgomery, D. 2007. Soil erosion and agricultural sustainability. Proceedings of the National Academy of Sciences, 104:13268-13272. http://dx.doi.org/10.1073/pnas.0611508104.

[26]Floerl, O., Inglis, G. \& Diettrich, J. 2016. Incorporating human behaviour into the risk-release relationship for invasion vectors: why targeting only the worst offenders can fail to reduce spread. Journal of Applied Ecology, 53:742-750. http://dx.doi.org/10.1111/13652664.12609.

[27]Ahn, J., Yang, C., Boyd, P., Pridal, D. \& Remus, J. 2013. Numerical modeling of sediment flushing from Lewis and Clark Lake. International Journal of Sediment Research, 28:182-193. http://dx.doi.org/10.1016/s1001-6279(13)60030-x.

[28]Chamoun, S., De Cesare, G. \& Schleiss, A. 2016. Managing reservoir sedimentation by venting turbidity currents: A review. International Journal of Sediment Research, 31:195-204. http://dx.doi.org/10.1016/j.ijsrc.2016.06.001. 
[29]Huffaker, R. \& Hotchkiss, R. 2016. Economic dynamics of reservoir sedimentation management: Optimal control with singularly perturbed equations of motion. Journal of Economic Dynamics and Control, 30:2553-2575. http://dx.doi.org/10.1016/j.jedc.2005.08.003.

[30]Bonachea, J., Bruschi, V., Hurtado, M., Forte, L., Da Silva, M. \& Etcheverry, R. 2010. Natural and human forcing in recent geomorphic change; case studies in the Rio de la Plata basin. Science of the Total Environment, 408:2674-2695. http://dx.doi.org/10.1016/j.scitotenv.2010.03.004.

[31] Hantush, M. \& Kalin, L. 2005. Uncertainty and sensitivity analysis of runoff and sediment yield in a small agricultural watershed with KINEROS2 / Analyse d'incertitude et de sensibilité des siPopulation density SY effectlations d'écoulement et de transport solide de KINEROS2 dans un petit bassin versant agricole. Hydrological Sciences Journal, 50. http://dx.doi.org/10.1623/hysj.2005.50.6.1151.

[32]Manux, E., Probst, J., Veyssy, E. \& Etcheber, H. 2001. Assessment of dam trapping efficiency from water residence time: Application to fluvial sediment transport in the Adour, Dordogne, and Garonne River Basins (France). Water Resources Research, 37:801-811. http://dx.doi.org/10.1029/2000wr900195.

[33]Fu, K. \& He, D. 2007. Analysis and prediction of sediment trapping efficiencies of the reservoirs in the mainstream of the Lancang River. Chinese Science Bulletin, 52:134-140. http://dx.doi.org/10.1007/s11434-007-7026-0.

[34]Regüés, D. \& Nadal-Romero, E. 2013. Uncertainty in the evaluation of sediment yield from badland areas: Suspended sediment transport estimated in the Araguás catchment (central Spanish Pyrenees). CATENA, 106:93-100. http://dx.doi.org/10.1016/j.catena.2012.05.006.

[35]Wu, C., Yang, S. \& Lei, Y. 2012. Quantifying the anthropogenic and climatic impacts on water discharge and sediment load in the Pearl River (Zhujiang), China (1954-2009). Journal of Hydrology, 452-453:190-204. http://dx.doi.org/10.1016/j.jhydrol.2012.05.064.

[36]Fang, H. 2017. Impact of Land Use Change and Dam Construction on Soil Erosion and Sediment Yield in the Black Soil Region, Northeastern China. Land Degradation \& Development, 28(4):1482-1492. http://dx.doi.org/10.1002/ldr.2677.

[37]Black, L.J. 2013. When visuals are boundary objects in system dynamics work. System Dynamics Review, 29(2):70-86. http://doi.org/10.1002/sdr

[38]Smakhtin, V., Hughes, D. \& Creuse-Naudin, E. 1997. Regionalization of daily flow characteristics in part of the Eastern Cape, South Africa. Hydrological Sciences Journal, 42:919-936. http://dx.doi.org/10.1080/02626669709492088.

[39]Department of Water and Sanitation. 2014. Feasibility Study for the Mzimvubu Water Project: Regional Economics, DWS Report No: P WMA 12/T30/00/5212/14.

[40]Statistics South Africa. 2012. Census 2011 Provinces at a glance. Pretoria: StatsSA.

[41]Madikizela, B.R., Dye, A.H. \& O'Keeffe, J.H. 2001. Water quality and faunal studies in the Umzimvubu catchment, Eastern Cape with particular emphasis on species as indicators of environmental change. Report to the Water Research Commission. Pretoria: Water Research Commission.

[42]Van Niekerk, L. \& Turpie, J.K. 2012. South African National Biodiversity Assessment 2011: Technical Report, Volume 3: Estuary Component, CSIR Report Number CSIR/NRE/ECOS/ER/2011/0045/B. Pretoria: Council for Scientific and Industrial Research.

[43]Department of Water and Sanitation. 2014. Feasibility Study for the Mzimvubu Water Project Reserve Determination: Volume 2: Estuary, DWS Report No: P WMA 12/T30/00/5212/7.

[44]Lamberth, S. \& Turpie, J. 2003. The Role of Estuaries in South African Fisheries: Economic Importance and Management Implications. African Journal of Marine Science, 25:131-157.

[45]Le Roux, J.J. 2018. Sediment Yield Potential in South Africa's Only Large River Network without a Dam: Implications for Water Resource Management. Land Degradation \& Development, 29(3):765-775. 
[46]Van der Waal, B.W. 2014. Sediment Connectivity in the Upper Thina Catchment, Eastern Cape, South Africa, Ph.D dissertation, Rhodes University, Grahamstown.

[47]Department of Water and Sanitation. 2014. Feasibility Study for the Mzimvubu Water Project: Cost Estimates and Economic Analysis DWS Report No: P WMA 12/T30/00/5212/15.

[48]Van Tol, J., Akpan, W., Kanuka, G., Ngesi, S. \& Lange, D. 2014. Soil erosion and dam dividends: science facts and rural 'fiction' around the Ntabelanga dam, Eastern Cape, South Africa. South African Geographical Journal, 98:169-181.

[49]Department of Water and Sanitation. 2014. Feasibility Study for the Mzimvubu Water Project: Water Resources DWS Report No: P WMA 12/T30/00/5212/5.

[50]Van der Waal, B.W. 2014. Sediment Connectivity in the Upper Thina Catchment, Eastern Cape, South Africa, Ph.D dissertation, Rhodes University, Grahamstown.

[51]Le Roux, J.J. \& Barker, C.H. 2015. Sediment yield modelling in the Mzimvubu River Catchment. Pretoria: Water Research Commission.

[52]ECSECC. 2014. Eastern Cape Joe Gqabi District: Socio-economic trends 2014. East London: ECSECC.

[53]ECSECC. 2014. Eastern Cape OR Tambo District: Socio-economic trends 2014. East London: ECSECC.

[54]Hall, D.T. 2002. Careers in and out of organizations. New York: Sage.

[55]Bruque, S., Moyano, J. \& Eisenberg, J. 2008. Individual adaptation to IT-induced change: The role of social networks. Journal of Management Information Systems, 25(3):177-206.

[56]Department of Water and Sanitation. 2014. Feasibility Study for the Mzimvubu Water Project: Geotechnical Investigations: Ntabelanga Dam DWS Report No: P WMA 12/T30/00/5212/10.

[57] Department of Environmental Affairs (DEA), Contract summaries of soft option restoration in T34B 01-07-14 to 04-04-16, Unpublished raw data (2016).

[58]Grange, N., Whitfield, A., De Villiers, C. \& Allanson, B. 2000. The response of two South African east coast estuaries to altered river flow regimes, Aquatic Conservation: Marine and Freshwater Ecosystems, 10:155-177.

[59]Whitfield, A. 1996. Fishes and the environmental status of South African estuaries. Fisheries Management and Ecology, 3:45-57.

[60]Sayer, J., Chokkalingam, U. \& Poulsen, J. 2004. The restoration of forest biodiversity and ecological values. Forest Ecology and Management, 201:3-11. http://dx.doi.org/10.1016/j.foreco.2004.06.008

[61]Nyssen, J.M., Veyret-Picot, M., Poesen, J., Moeyersons, J., Haile, M., Deckers, J. \& Govers, G. 2004. The effectiveness of loose rock check dams for gully control in Tigray, northern Ethiopia. Soil Use and Management, 20:55-64.

[62]Norton, J.B., Boannie, F., Peynesta, P., Quandelacy, W. \& Siebert, S.F. 2002. Native American methods for conservation and restoration of semiarid ephemeral streams. Journal of soil and Water Conservation, 57:250-258.

[63]Polyakov, V., Nichols, M., McClaran, M. \& Nearing, M. 2014. Effect of check dams on runoff, sediment yield, and retention on small semiarid watersheds. Journal of Soil and Water Conservation, 69:414-421, http://dx.doi.org/10.2489/jswc.69.5.414 


\section{Annex 1: Data}

Parameters used in the Ntabelanga and Laleni dam catchment sub-model

\begin{tabular}{|c|c|c|c|}
\hline & Unit & Value & Source \\
\hline Initial yield N & $\mathrm{m}^{3} / \mathrm{a}$ & $20,000,000$ & DWS [39] \\
\hline Trapping Efficiency L & $\%$ & 0.96 & Own calculation \\
\hline Trapping Efficiency $\mathrm{N}$ & $\%$ & 0.987 & Own calculation \\
\hline Construction period both dams & Dmnl & 60 & DWS [47] \\
\hline Delay dam building & Dmnl & 24 & Assumption \\
\hline Initial storage Laleni & $\mathrm{m}^{3}$ & $231,000,000$ & DWS [39] \\
\hline Initial storage Ntabelanga & $\mathrm{m}^{3}$ & $490,000,000$ & DWS [39] \\
\hline Dead storage Ntabelanga & $\mathrm{m}^{3}$ & $29,300,000$ & DWS [39] \\
\hline Sediment yield initial & t/ha/year & 72 & Calculated using Le Roux \& Barker [50] \\
\hline Average depth of erodible soil & $\mathrm{M}$ & 3 & Own estimated from DWS [49] \\
\hline Soil density & $\mathrm{t} / \mathrm{m}^{3}$ & 1.6 & Le Roux \& Barker [50] \\
\hline Estuary $\mathrm{Ha}$ & $\mathrm{Ha}$ & 150 & DWS [43] \\
\hline Catchment area & $\mathrm{Ha}$ & $2,000,000$ & DWS [56] \\
\hline Laleni dam catchment area & $\mathrm{Ha}$ & 188,221 & DWS [56] \\
\hline Ntabelanga dam catchment area & $\mathrm{Ha}$ & 197,178 & DWS [56] \\
\hline Electricity & MWh/annum & $202,438.247$ & DWS [47] \\
\hline Price electricity & $\mathrm{R} / \mathrm{MWh}$ & 769.32 & DWS [47] \\
\hline $\begin{array}{l}\text { Income addition } \% \text { due to } \\
\text { construction }\end{array}$ & $\begin{array}{c}\% / \text { construction } \\
\text { period }\end{array}$ & 17.7 & DWS [39] \\
\hline Income addition \% due to operation & $\begin{array}{l}\text { \%/dameconomic } \\
\text { lifespan }\end{array}$ & 7.5 & DWS [39] \\
\hline Household Income Growth & $\%$ & 2.684 & $\begin{array}{l}\text { Own estimate calculated from Statistics } \\
\text { South Africa [44] }\end{array}$ \\
\hline Impact of income & $\%$ & 10 & Own calculation \\
\hline Initial household income & R/month & 3770.55 & {$[39]$} \\
\hline Initial population & people & $1,702,830$ & Own estimate calculated from $[54,55]$ \\
\hline Impact soil loss & $\%$ & $5 e-10$ & Own calculation \\
\hline Impact estuary & $\%$ & 0.01 & Own calculation \\
\hline People per household & People & 5 & Own calculation \\
\hline Tolerable population density & People/ha & 200 & Own calculation \\
\hline Cost containment factor & Dmnl & 0 & Assumption \\
\hline Benefit containment factor & Dmnl & 1 & Assumption \\
\hline Response time & Dmnl & 1 & Assumption \\
\hline Sediment yield effect delay & Month & 60 & Assumption \\
\hline Water quality effect delay & Month & 60 & Assumption \\
\hline Monthly Birth rate & $\mathrm{Dmnl}$ & 0.09688 & ECSECC $[52,53]$ \\
\hline Monthly Death rate & Dmnl & 0.000705 & ECSECC $[52,53]$ \\
\hline Monthly Migration rate & $\mathrm{Dmnl}$ & 0.001345 & ECSECC $[52,53]$ \\
\hline Income Migration delay & Month & 24 & Own calculation \\
\hline Cost estuary suitability & R/ha/annum & $44,924.93$ & Lamberth \& Turpie [44] \\
\hline Mean annual runoff 2014 & $m^{3}$ /annum & 2,897 & DWS [56] \\
\hline Rest budget & $\mathrm{Rm}$ & 450 & DWS [47] \\
\hline Sediment yield restoration effect & $\begin{array}{c}\text { t/ha/year/restoration } \\
\text { duration }\end{array}$ & 0.5 & Own calculation \\
\hline Restoration duration & Months & 120 & DWS [47] \\
\hline Proportion spent on SO N & $\%$ & 0.5 & DWS [47] \\
\hline Restoration intensity & Dmnl & 0.0006 & Own calculation \\
\hline Restoration cost per ha & $\mathrm{Ha}$ & 239,931 & DEA [57] \\
\hline $\begin{array}{l}\text { Initial probability of restoration } \\
\text { failure }\end{array}$ & $\%$ & 0.05 & Own calculation \\
\hline Rate of substitution initial & Dmnl & 0.2 & Assumption \\
\hline
\end{tabular}




\section{Annex 2: Model description}

The numbers below refer to the numbered links within Figure 2 (Section 3.3).

\section{$1-3$}

The stock of material susceptible to water erosion is reduced through soil loss. Using an average rate of soil erosion ( $\mathrm{t} / \mathrm{ha} /$ annum) the amount of soil eroded in the catchment in period $t$ is calculated and the sediment yield is estimated using the sediment delivery ratio variable. It is expected that a reduction over time in average soil erosion rate or in the sediment delivery ratio will result in a shift upward (\#1 in Figure A2-1) of the soil mass curve over time, while an increase in the sediment delivery ratio or the rate of soil erosion over time will result in a shift downward (\#2 in Figure A2-1) of the soil mass curve over time.

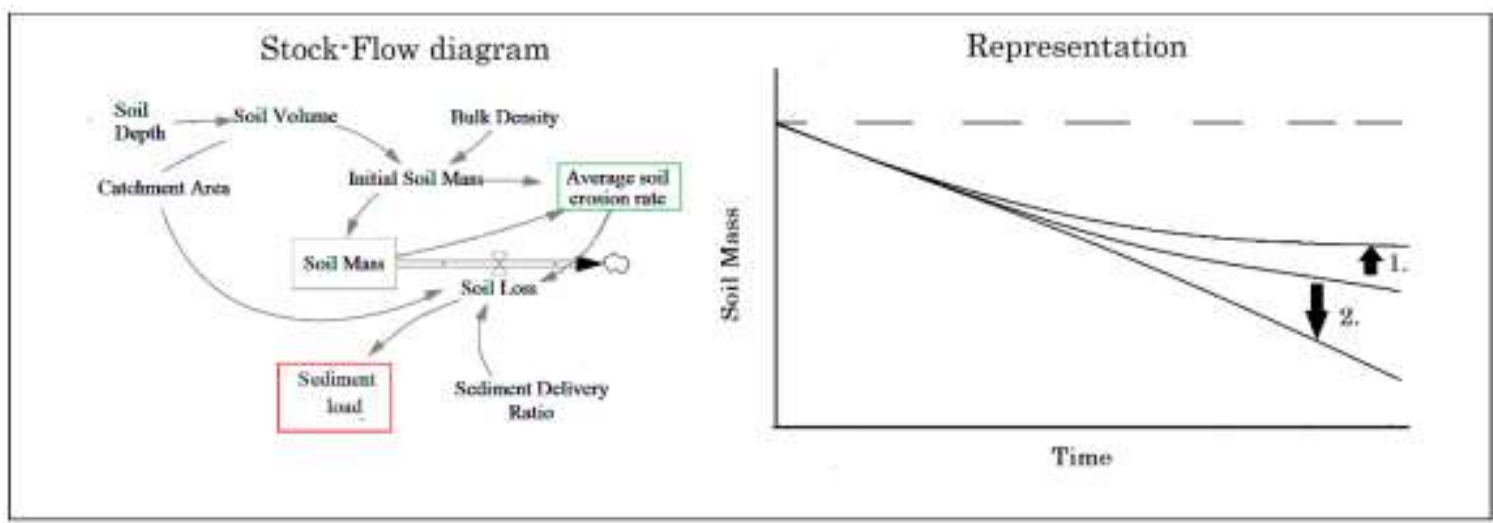

Figure A2-1 Conceptual model for soil erosion with illustration of expected output under increases and decreases for average soil erosion rate

4

Most households in the study area augment household income with subsistence agriculture. We assume that soil erosion has an impact on soil fertility to the detriment of these households [4*]. We calculate cumulative soil lost from the catchment as a stock. In each period we assume some small percentage (see Annex 1 ) called Impact soil loss, acts negatively on the household income growth rate.

5-10

We assume that higher income will convince more people to delay out-migration, subject to an acceptable population density. As illustrated in Figure A2-2, a consistent increase in household income is expected to reduce the out-migration rate and might even result in in-migration. Subject to a 24-month delay (Annex 1 ) we model a \% reduction of the out-migration rate as follows:

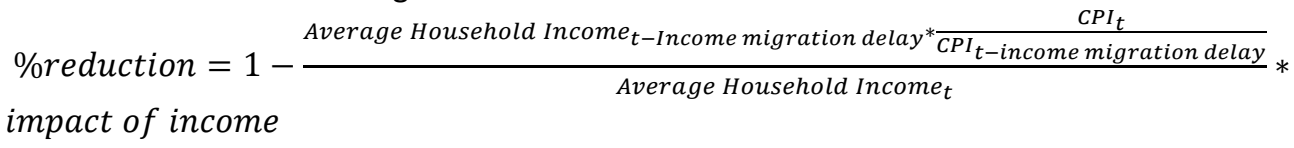

If, in real terms, for some month $t$, should households observe real household income to be lower than it was the same month 2 years prior, the migration rate increases and more people leave the catchment in search of opportunity. As soon as the population density (people/ha) increases above some tolerable population density value the \% reduction of the out-migration rate is modelled as follows:

$$
\begin{aligned}
& \text { Average Household Income } \text { I-Income migration delay } * \frac{C P I_{t}}{C P I_{t-\text { income migration delay }}}
\end{aligned}
$$

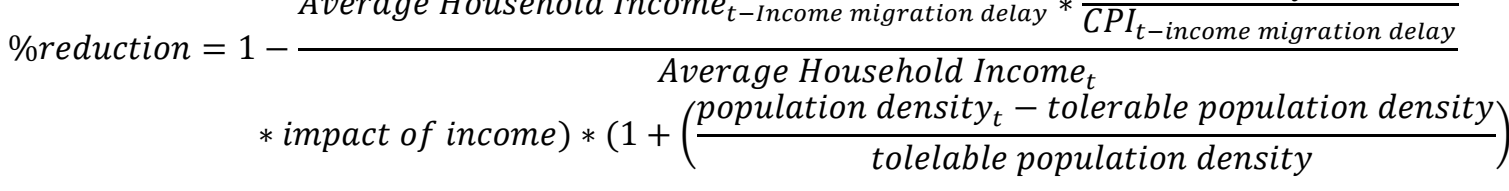




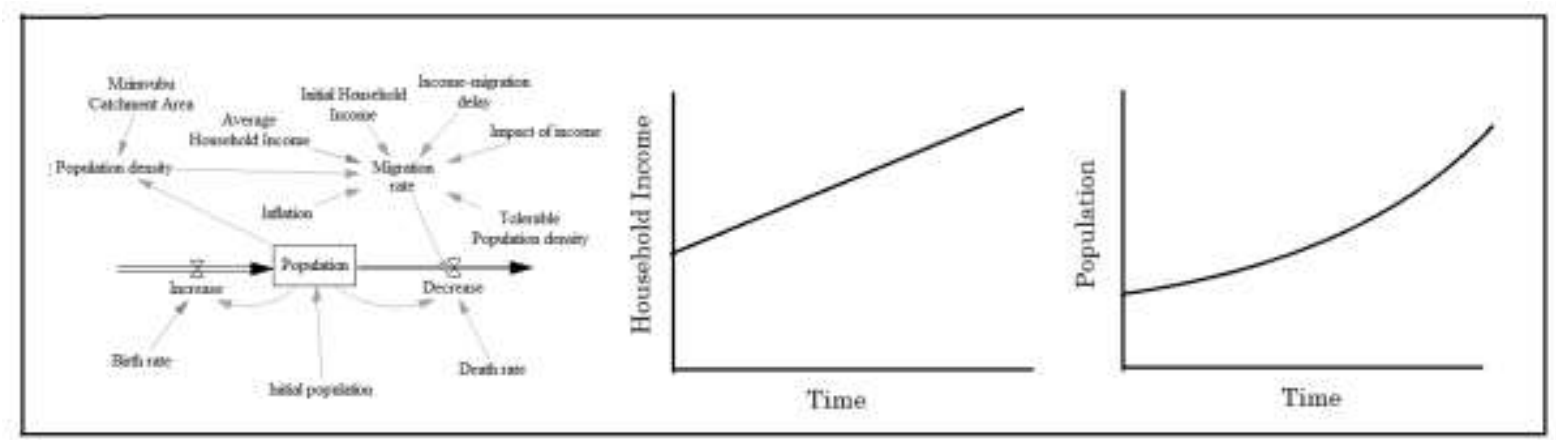

Figure A2-2 Conceptual model for population dynamics with illustration of expected output for population variable given constant increase in household income

\section{2-13}

We model dam storage as a stock that is depleted over time as sediment is deposited in it [13]. We do not model the flow of water given the required temporal and spatial scale as well as data scarcity. The stock and flow diagram in Figure A2-3 shows how we combine factors in Table 1 calculating the siltation effect as follows:

and,

$$
\text { Siltation effect } t_{t}=\frac{\text { Bulk Density }}{\text { Trap Efficiency } * \text { Sediment load }}
$$

with,

$$
\text { Dam Storage }_{t}=\text { Dam Storage }_{t-1}-\text { Siltation effect } t_{t}
$$

$$
\text { Dam Storage }_{0}=\text { Innitial Storage Capacity }
$$

The graphical representation of what we expect to happen to storage over time is also presented in Figure A23. We define lifespan here as the complete loss of storage. As the sediment load in time $t$ is variable, an increase in sediment load over time should be represented graphically as a decrease in lifespan (\#1 in figure A2-3). A reduction in the sediment load, either through change in land use and population or as a result of restoration and catchment management, should be represented by an increase in lifespan.

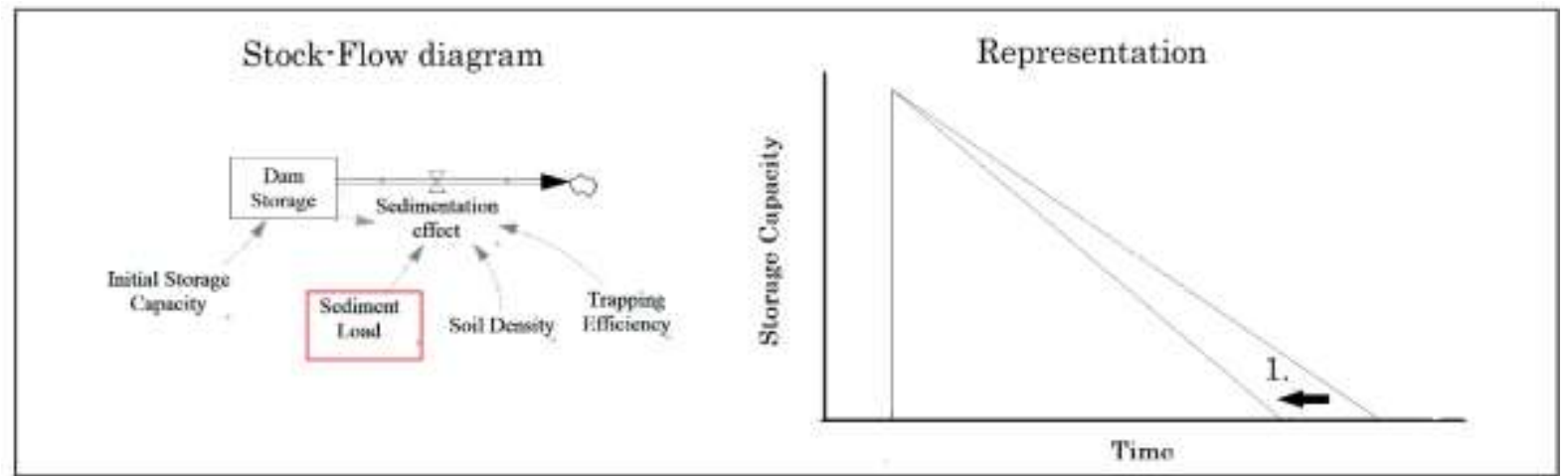

Figure A2-3 Conceptual model for dam sedimentation with illustration of expected output and behaviour for varying sediment load

14

The benefits of the MWP are expressed in increases in household income [39] dependant on whether dams are still under construction or are already in full operation. If both dams silt, all upward pressure on household income growth rate stops. Higher household income growth rate under the MWP is modelled as additions to basic growth rate which we take to be equal to the expansion of national social grant expenditure received [44]. We construct a variable called "benefit containment factor" as a real number ranging between 0 and 1 . This allows one to control the proportion of MWP benefits in terms of wages are earned by households in the Mzimvubu river catchment. Similarly, we construct a variable called "cost containment factor" as a real number which ranges between 0 and 1 indicating what proportion of the environmental costs (including the impact of sedimentation hydropower production in the Laleni dam) negatively affect household income. We assume that, should the Laleni dam be completely silted up, no hydropower will be produced by it. Should this occur before 
the Ntabelanga dam is completely silted up then it will have implications for the projected annual household income growth for when the Ntabelanga dam is operational.

\section{5-19}

To ensure that changes in estuary health are considered in the model, we construct an index measuring the suitability of the estuary for fish with year 1 as base year that fluctuates with water turbidity and salinity. The index will fluctuate, brought on by human behavioural changes in water use in response to rising incomes, or indirectly through aggravated soil loss. We multiply the value of the deviation of this index relative to its base year value with Lamberth and Turpie's [44] estimate for the value of fish caught per estuary hectare. By including a variable Estuary impact in our simulations we can allow some of this cost to be internalised in the study area as downward pressure on income growth.

The Department of Water and Sanitation [43] predicted the magnitudes of changes in turbidity and salinity to occur in the estuary upon completion of the Ntabelanga dam. The average turbidity in the estuary was 174 NTU (nephelometric turbidity units) in 2014 and is modelled to increase to 181.33 NTU upon completion of both dams. By building the Ntabelanga dam, a reduction in mean annual runoff of $2 \%$ percent is estimated [43]. In response, the salinity in the lower region of the estuary, which was 13 PSU (practical salinity unit) in 2014, is modelled to increase to 18 PSU upon the completion of the Ntabelanga dam. We estimate a relationship between turbidity in the estuary, sediment yield and mean annual runoff in the Mzimvubu river catchment in equation 1.

$$
\text { Turbidity in estuar } y_{t}=\frac{\text { total soil loss } M Z_{t}}{M A R_{t}-\left(\text { Yield } N_{t}\right) * 2 \mathrm{e}-005} *\left(\frac{1}{11}\right) \text {... }
$$

Using the available predictions on the effect of the Ntabelanga dam on salinity in the lower reaches of the estuary, we estimate equation 2. Equation 2 describes a possible relationship between mean annual runoff, dam yield and salinity in the estuary at time $t$ :

$$
\text { Salinity in estuary } \text { e }_{t}=M A R_{2014} * \frac{M A R_{2014}}{M A R_{t}} * 12+\frac{\text { Yield } N_{t}}{M A R_{t}} * 0.0001
$$

For subtropical estuaries in the Eastern Cape, Whitfield [58] reported an increase in fish abundance of $100 \%$ in response to a reduction in salinity of $30 \%$. Grange et al. [59] observe a positive correlation between fish abundance and turbidity for estuaries in the Eastern Cape. We assume that the increase in the index brought about by an increase in turbidity decreases the further current turbidity levels from reference turbidity. We estimate a relationship (equation 3 ) between the suitability of the estuary for fish, turbidity and salinity:

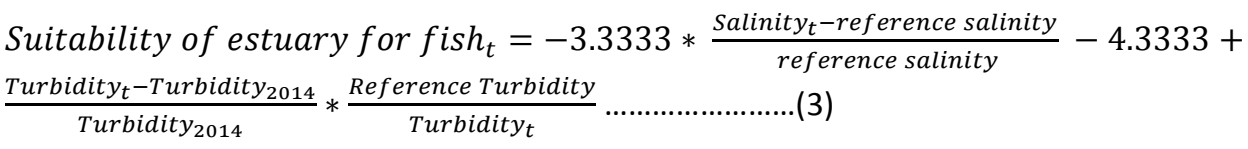

\section{$11,21-23$}

We assume that human behaviour varies with changes in income. We consider three plausible environmental consequences of human behaviour changes for rising income illustrated in Figure A2-4 below and modelled with a switch named "subst. switch":

1. Subst. switch value $=0$ specifies the substitution trajectory (as income rises) of behavioural change that does not alter the impact humans have on the environment.

2. Undesirable substitution activated for Subst. switch value $=1$ is the substitution trajectory (as income rises) of behavioural changes that have an increasingly negative impact on the environment as the scale of economic activity increases.

3. Desirable substitution activated for Subst. switch value $=2$ is the substitution trajectory (as income rises) of behavioural changes that have a decreasingly negative impact on the environment as the scale of economic activity increases. 


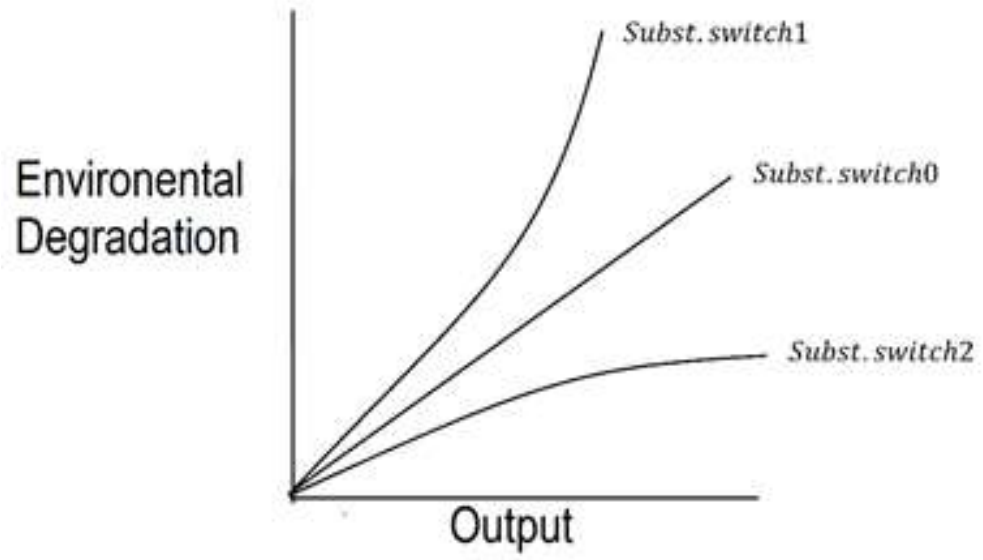

\section{Figure A2-4 Possible changes in the technological trajectories}

To model these three scenarios, we make use of three variables:

1. The impact of a change in behaviour on water quality or sediment yield is modelled using an elasticity. This is a measure of the environmental costs incurred by spending additional income or by the behaviours additional income encourages.

2. The speed with which behaviours are changed after an increase in income is realised (response time).

3. The delay until the impact of this new behaviour becomes observable in the environment.

We model, subject to a delay, an income sediment yield elasticity as follows:

$$
\text { Income sediment yield elastcity }=\frac{\% \Delta \text { Sediment yield }}{\% \Delta \text { Annual average household income }}
$$

Elasticities for population density is modelled in a similar way. To acknowledge the possibility that behavioural changes in water use could influence estuarine production downstream, we develop an Income water quality elasticity and subject to some delay model the impact of rising incomes on the Suitability of estuary for fish index.

\section{4}

The effect of gully restoration over the project lifespan has been observed to reduce sediment yield by $44 \%$ [30]. The success rates of the projects vary considerably [60] often as a result of failure to inform and obtain the cooperation of all stakeholders [61]. Evidence that the rate at which restoration structures fail also vary across structure types and catchment as summarised in Table A2-1. We model a success rate of restoration (stock-flow arrangement seen in Figure A2-5) that takes into account the rate of structure failure and the impact on the SY rate, which, assuming that the type of restoration applied to an area is best practice and completive.

Table A2-1 Rate at which restoration structures fail

\begin{tabular}{|l|l|l|}
\hline Structure failure & Type of restoration & Reference \\
\hline $39 \%$ & Check dams & {$[61]$} \\
\hline $60 \%$ & Check dams & {$[53]$} \\
\hline $22 \%$ & Bush structures & \\
\hline $34 \%$ & Check dams & {$[62]$} \\
\hline $21.74 \%$ & Bush Structures & \\
\hline $13.51 \%$ & Check dams & {$[63]$} \\
\hline
\end{tabular}

As R450 million has been allocated to restoration in the Laleni dam and Ntabelanga dam catchments [39], a component is included to account for the effects of such restoration on the rate of soil erosion in the region. A soft option restoration programme (i.e. ponding, silt fences, eco-logs, rock packs and sloping) is modelled using contract data provided by the Department of Environmental Affairs [57]. We define the restoration success as a function of the probability of structure failure and the percentage reduction in sediment yield produced over 
the restoration period on the area of land identified for restoration. We construct a sub-model for restoration using cost data for a restoration project near the Ntabelanga dam catchment and model the stock Restoration expenditure and how it drained over the restoration program lifespan by assuming that spending over the project lifespan follows a sigmoidal function and that there are delays between spending on materials and labour and the actual installation of structures. The variable Speed of substitution is introduced to model changes in the relative effectiveness of land/catchment management brought on by technology substitution in response to rising incomes. The variable Substitution Switch allows one to specify whether future technologies adopted in the catchment strengthen, weaken or ensure that the relative effectiveness of catchment/land management remains unaltered. The probability of structure failure is affected by the willingness of the population to regard these structures as useful technology for which speed of substitution is used as proxy.

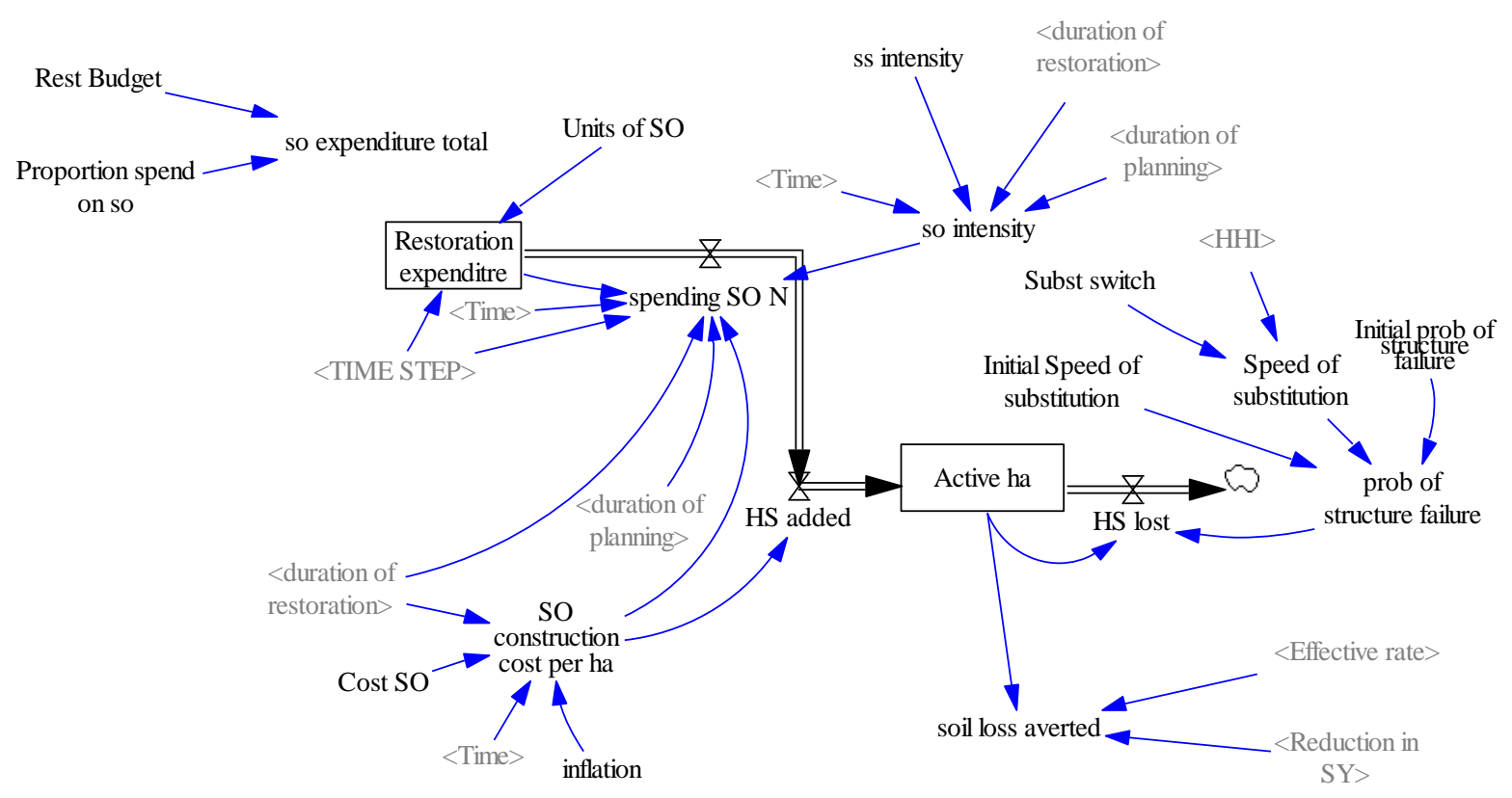

Figure A2-5 Soft option restoration in Ntabelanga dam catchment

Source: Own construction

\section{Annex 3: Model validation}

\section{Dimensional consistency test}

A dimensional consistency test was performed and passed ensuring that equations used to establish mathematical relationships were scientifically sound.

\section{Behavioural tests}

Turbidity and salinity modelling results in DWS [39] with average turbidity in the estuary at 175 NTU before the dam and 181 NTU after dam construction and lower zone estuary current 12 PSU and 18 PSU after dam construction. Le Roux and Barker [50] calculated a siltation effect, average sediment deposited into the Ntabelanga dam per month of 888000 tons, this is replicated by the model when the feedback causing alterations to sediment yield rates are deactivated.

\section{Parameter verification tests}

The majority of data was sourced from organisations that operate in the catchment or from available literature. Certain parameters were assumed. Sensitivity analysis around many of the assumed parameters such as Rate of substitution factor, cost containment factor, various delays and benefit containment factor are found in the results showing how sensitive the output is to small changes in assumed parameters. 


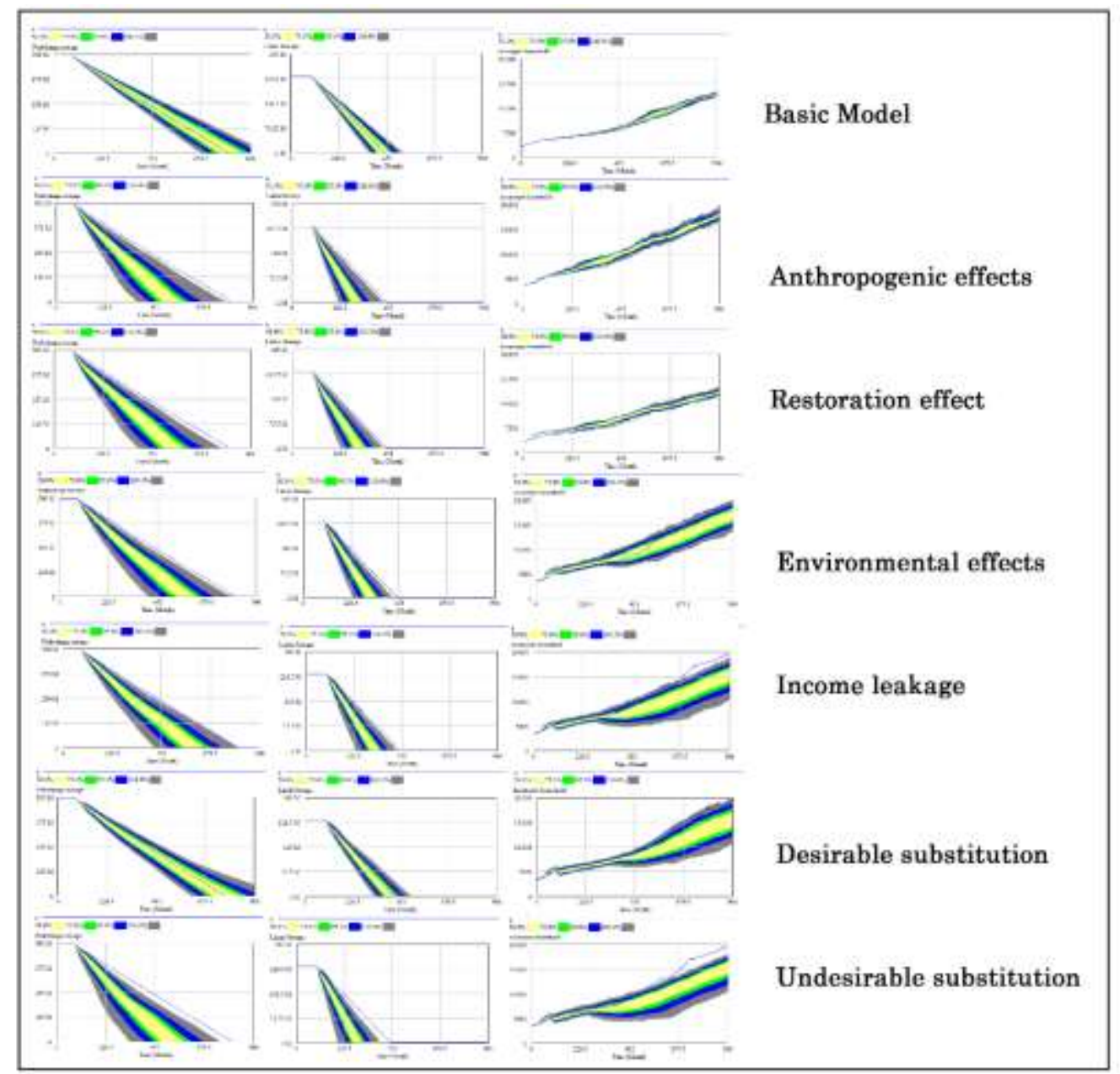

Figure A4-1 Output showing the impact of parameter mix variations on the Ntabelanga dam lifespan, Laleni dam lifespan and household income. 